\title{
STRUKTUR DAN FUNGSI LAGU BANJAR KARYA H. ANANG ARDIANSYAH
}

\author{
Kamariah \\ Email: kamariah@stkippgribjm.ac.id \\ STIKIP PGRI Banjarmasin \\ Ngalimun \\ . ngalimun@akparnas.ac.id \\ AKPARNAS Banjarmasin
}

\begin{abstract}
The purpose of this research is to study the structure and function of the Banjar regional songs. Besides carrying out the mission of revitalizing Banjar culture which has begun to become extinct along with the times. This research uses descriptive method so the results of this study are the results of research on Banjar by H. Anang Ardiansyah. For accurate and understandable analysis data, this study uses an objective method, which is based on the literary work itself. This method is expected to reveal the form and function contained in the Banjar song.

The structure of the Banjar song by H. Anang Ardiansyah can be changed into two, namely the repetition of parts and repetition with changes. Bait full repeat loop. Repetition with the changes requested in the repetition of feedback in the first few lines is the same, but in several lines after the change in feedback. This research also succeeded in formulating four functions of the Banjar song, namely the function of educating or helping, entertaining, criticizing, and expressing feelings.
\end{abstract}

Keywords: structure, function, Banjar song

\section{PENDAHULUAN}

H. Anang Ardiansyah adalah maestro lagu-lagu daerah Banjar. Diantara kompuser dan penyanyi lagu Banjar lainnya, seperti A. Hamid, A. Thamrin, Agit Kursani, Hamka, Mas'uddan lain-lain, beliau adalah yang paling berpengaruh. Lagu-lagu ciptaan H. Anang Ardiansyah yang telah di albumkan mencapai 103 judul, hal itu membuktikan bahwa beliau adalah penulis lagu yang sangat produktif. Lagu-lagu ciptaannya mengandung unsur budaya Banjar yang sangat kuat dengan menggunakan bahasa Banjar Arkais (Banjar kuno). Dengan media lagu-lagu ciptaannya tersebut H. Anang Ardiyansyah mempunyai misi memperkenalkan dan melestarikan bahasa dan kebudayaan Banjar. Rafiek (2012:60) mengatakan bahwa Kalimantan Selatan adalah daerah yang kaya akan budaya dan sastra klasik, budaya dan sastra tersebut ada yang masih bisa ditemui sampai saat ini atau bahkan sudah punah ditelan zaman.Akhrirnya kekayaan tersebut dapat diperkenalkan kembali oleh H. Anang Ardiyansyah melalui media yang populer dan disukai oleh masyarakat, yaitu lagu. Hal tersebut sejalan dengan pendapat Mannion dan Sanatullova (2012) menurut mereka lagu dan budaya mempunyai sifat reflektif dan generatif, saling berhubungan dan mempengaruhi sebagai alat komunikatif. Berdasarkan teori realivitas linguistik yang mereka terapkan, untuk menjelaskan mengenai posisi keberadaan manusia dalam suatu kebudayaan bisa dipahami dari mengkaji hubungan antara musik, kata dan budaya. 
Dalam banyak literatur, khusunya pengkajian sastra hampir semua jenis karya sastra memiliki sebuah struktur.Struktur merupakan ruang lingkup yang tidak dapat dipisahkan dari jenis karya sastra, baik itu jenis prosa, puisi, maupun bahasa yang berirama yang disebut lagu.Struktur merupakan satu kesatuan organik seperti tangan, kaki, dan otak yang membangun sirkulasi serta menjadi satu kesatuan orgaik yang disebut tubuh.Kaum strukturalis mengganggap karya sastra merupakan sebuah struktur yang unsur-unsurnya atau bagian-bagiannya saling bertalian erat dalam struktur itu, unsur-unsur tidak mempunyai makna dengan sendirinya.Makna ditentukan oleh hubungan dengan unsur-unsur lainnya dalam keseluruhan atau totalitas.(Hawkes dalam Saro, 1993).Selain itu, Teeuw (1983) juga berpendapat bahwa makna unsur-unsur karya sastra itu hanya dapat dipahami dan dinilai sepenuhnya atas dasar pemahaman tempat dan fungsi karya satra itu dalam keseluruhan karya sastra.

Dengan demikian, sebuah lagu tidak hanya berurusan dengan "apa yang disampaikan" tetapi juga "bagaimana cara menyampaikannya". Berdasarkan konteks tersebutsebuah lagubisa saja memiliki tuntunan bentuk orientasi ekspresi yang berbeda dalam bentuk pengucapannya. Contohnya dalam karyasastra lisan berbentuk puisi, memiliki struktur yang berhubungan dengan (a) jumlah baris, (b) pola persajakan yang berhubungan dengan rima, aliterasi, asonansi, irama, gaya bahasa kiasan (simile, metafora, metonimia, sinekdok, dan personifikasi).

Dalam sastra lisan menurut Teeuw (Tutoli, 1990) bahwa fungsi sastra dalam masyarakat sering masih lebih wajar dan langsung terbuka untuk penelitian ilmiah khususnya masalah hubungan antarafungsi estetik dan fungsi lain (agama, sosial). Sebagai produk karya sastra masyarakat masa lalu, sastra lisan juga merupakan peninggalan nenek moyang yang merupakan ungkapan ekspresi dan pancaran masyarakat (Alisyahbana, 1983).Hal tersebut juga tidak jauh berbeda dengan keadaan pada masa sekarang yang mana masyarakat saat ini juga gemar mengungkapkan segala sesuatunya melalui lagu.

Berdasarkan hal tersebut, yang terpenting dalam sastra lisan adalah isi dan tujuan, serta hal-hal yang tersirat di dalamnya yang berkaitan dengan masyarakat.Selain itu, dampak sosial karya sastra itu sendiri juga merupakan sesuatu yang harus diperhatikan (Wellek, 1989).Namun ada pula ahli yang berpendapat bahwa hal yang penting dalam mengetahui tujuan dan fungsi karya sastra lisan adalah hubungannya dengan kepercayaan, agama, pengalaman, dan lambanglambang khusus yang bersifat lokal (Finegen dalam Tutoli, 1990).

Fungsi-fungsi sastra lisan juga berkenaan dengan (1) fungsi mendidik atau memberi nasihat (educational function), (2) fungsi kritik sosial (social function), (3) fungsi hiburan (art function), (4) fungsi ungkapan perasaan.Fungsi-fungsi ini melekat pada konteks pemakaian sastra lisan.Fungsi tersebut tidak terlepas dari keperluan hiburan, sebagai upacara keagamaan, sebagai alat hubungan pergaulan baik orang tua maupun para remaja (Teeuw dalam Saro, 1993).

Mengingat fungsi-fungsi tersebut khazanah sastra lisan perlu terus dijaga kelestariannya sebagai cagar budaya.Karena karya sastra tersebut telah dikenal oleh masyarakat kita berabadabad yang lalu dan telah membentuk pola pikir, sistem sosial, dan sistem budaya masyarakat yang meyakininya dan sekaligus sebagai bagian dari budaya yang dimilikinya.

\section{METODE PENELITIAN}

Metode yang digunakan untuk menganalisis data adalah metode deskriptif karena hasil penelitian ini berusaha menggambarkan isi dari lagu Banjar karya H. Anang Ardiansyah.Untuk menganalisis data secara cermat dan komprehensif, dalam penelitian ini digunakan pendekatan objektif, yaitu pendekatan yang bertolak dari karya sastra itu sendiri sesuai dengan asumsi bahwa penelitian sastra seharusnya bertolak dari interpretasi dan analisis karya sastra itu sendiri (Wellk 
dan Warren, 1989). Dengan metode ini diharapkan dapat mengungkapkan bentuk dan fungsi yang terkandung dalam lagu Banjar tersebut.

\section{HASIL DAN PEMBAHASAN \\ Struktur Lagu}

Struktur lagu yang dibahas pada bagian ini mempersoalkan hubungan antara unsur-unsur lirik dalam lagu dari segi pengulangan.Repetisi menjadi salah satu struktur lagu yang sering muncul dalam lagu. H. Anang Ardiansyah selalu menggunakan repetisi pada tingkat baris hingga bait. Pembahasan akan dibagi menjadi dua bagian, yaitupengulangan suatu bagian dan pengulangan dengan perubahan.Pembahasannya adalah sebagai berikut.

\section{Pengulangan Suatu Bagian}

H. Anang Ardiansyah kadang membuat pengulangan suatu bait secara penuh tanpa mengalami perubahan. Hal ini sering dilakukan. Meskipun demikian, cara menyanyikannya tidak sama antara bait yang satu dan bait yang lain. Biasanya bait yang lebih awal lebih rendah nadanya dibandingkan bait yang sama sesudahnya. Hal ini dapat diamati pada lagu berjudul Latifah.Oleh sebab itu, dinamikalagu tetap terjaga, dan pendengarnya tidak mengalami kebosanan.Bait yang mengalami perulangan adalah sebagai berikut.

Ikamkah nang mangaji wayah bamekratan malam tadi

Taranai urang nang mandangari

Rasa taparak banar wan takdir ilahi

Artinya

(Apakah engkau yang mengaji ketika acara peringatan Isra dan Miraj dulu)

(Orang yang mendengarkan terdiam)

(Rasa lebih dekat dengan takdir ilahi)

(H. Anang Ardiansyah, Latifah)

Lirik-lirik ini pertama kali dinyanyikan pada bait kedua. Selanjutnya, pada bait keempat, bait ini kembali diulang secara penuh. Tidak ada perubahan sama sekali pada bait-bait tersebut. Pengulangan ini bertujuan untuk menegaskan pesan utama yang ingin disampaikan oleh $\mathrm{H}$. Anang Ardiansyah dalam lagunya, yaitu dia terpesona dengan kemerduan suara Latifah yang mengaji ketika ada acara Isra dan Mi'raj.Kemerduan suaranya membuat orang-orang yang hadir saat itu terdiam karena merasakan keindahan. Pesan ini menjadi lebih menonjol karena didengarkan lebih dari satu kali dalam lagu yang sama.

Lagu lain yang menggunakan bentuk pengulangan bagian dapat diamati pada lagu berjudul Maiwak atau mencari ikan. Pengulangannya secara penuh tanpa mengalami perubahan sedikitpun.Pengulangan yang dimaksud adalah sebagai berikut.

Tangkisung ka tanjung sila, ayu

Jukung hibak lalu sarat hibak

Kulihan gasan manfaat jadi

Rajaki sakaluarga kami

Artinya

(Tangkisung ke Tanjung Sila, ayo)

(Perahu penuh, kemudian sangat penuh)

(Hasil untuk menjadi manfaat)

(Rezeki kami sekeluarga) 
Volume 7 Nomor 1, April 2021

\section{(H. Anang Ardiansyah, Maiwak)}

Kutipan ini terdiri dari empat baris yang terdapat pada bait 4 dan 6. H. Anang Ardiansyah mengulangi bait ini sebanyak dua kali dalam lagunya. Sebagaimana sebelumnya, tidak ada perubahan apapun pada kedua bait tersebut.Pengulangan ini membuat pesan tentang rezeki yang diperoleh dari mencari ikan di laut menjadi lebih mudah diserap oleh pendengarnya.

Pengulangan seperti ini juga terlihatlagu lain yang berjudul Kambang Goyang. Pengualangan yang sama persis ini membuat irama lagu menjadi menarik. Hal ini terlihat pada kutipan berikut ini.

Uraiakan mayang nang sakti

Umpatakan balarut banyu

Adat raja bamandi-mandi

Artinya

(Sebarkan mayang yang sakti)

(Ikutsertakan air mengalir)

(Adat raja bamandi-mandi)

(H. Anang Ardiansyah, Kambang Goyang)

Kutipan ini terdapat pada lagu berjudul Kambang Goyang. Ketiga baris ini terdapat pada bait empat dan lima. Keduanya berada pada akhir lagu. Pengulangan ini membuat lagu berakhir dengan irama yang manis. Penyanyi akan menurunkan irama dan nadanya di akhir lagu agar pendengar dapat menikmati bagian akhir lagu ini.Pengulangan yang sama persis ini membuat penyanyi dapat dengan mudah mengatur nada yang akan digunakan karena liriknya sama.

\section{Pengulangan dengan Perubahan}

Pengulangan dalam lagu $\mathrm{H}$. Anang Ardiansyah juga terjadi dalam bentuk perubahan. Pengulangan yang dimaksud ialah pengulangan bait pada beberapa baris pertama memang sama, tetapi pada beberapa baris sesudahnya mengalami perubahan. Perubahan ini menyesuaikan dengan lirik sebelumnya sehingga lagu ini masih memiliki suatu alur cerita.Pengulangan seperti ini dapat diamati pada kutipan berikut ini.

Luka di tangan kawa di babat a...wan $2 x$

Luka di hati luka di hati hancur sakali

Artinya

(Luka di tangan bisa diperban)

(Luka di hati hancur sekali)

(H. Anang Ardiansyah, Damar Wulan)

Lirik ini terdapat pada lagu berjudul Damar Wulan pada baris 6 sampai baris 8. Pada baris 6 dan 7, isinya sama persis tanpa mengalami perubahan. Namun, pada bait kedelapan H. Anang Ardiansyah hanya mengulang kata pertama, yaitu "luka di".Kata-kata setelahnya berbeda.Sebelumnya, penulis mengatakan luka di tangan kawa dibabat, sedangkan pada baris selanjutnya diganti menjadi luka di hati, luka di hati hancur sekali.Pengulangan ini membuat adanya jalinan hubungan antara baris yang satu dan baris setelahnya.Selain itu, lagu yang dinyanyikan menjadi lebih mudah diingat dan lebih enak untuk didengar.

Lagu lain yang menggunakan bentuk pengulangan seperti ini juga terlihat pada lagu berjudul Curiak. H. Anang Ardiansyah langsung menggunakan pengulangan pada bait pertama 
dan kedua, tetapi denganperubahan pada beberapa baris terakhir di setiap bait. Kutipan lagu yang dimaksud adalah sebagai berikut.

Curiak siburung palung

Bahinggap dikayu mati

Bakuriak maminta tulung

Tali salawar tajarat mati

Curiak siburung palung

Bagantung dipuhun baruh

Bakuriak maminta tulung

Mun tumbal kurung tajajak paku

Artinya

(Curiak si burung palung)

(menghinggapi kayu mati)

(Berteriak meminta tolong)

(Tali celana terikat mati)

(Curiak di burung palung)

(Bergantung di pohon baruh)

(Berteriak meminta tolong)

(Bila tumbalkurung terinjak paku)

Kedua bait ini memiliki persamaan di baris pertama dan ketiga, tetapi berbeda pada baris kedua dan keempat. Persamaannya ialah baris pertama sama-sama menggunakan lirik "Curiak siburung palung" dan baris ketiga menggunakan "Bakuriak maminta tulung". Adapun perbedaannya, bila bait perama baris kedua berisi "Bahinggap dikayu mati", sedangkan bait kedua berisi "Bagantung dipuhun baruh". Adapun bait pertama baris keempat yang awalnya berbunyi "Tali salawar tajarat mati", sedangkan bait kedua baris keempatnya berbunyi "Mun tumbal kurung tajajak paku”.

\section{Fungsi Lagu}

Bagian ini membahas tentang fungsi yang dimiliki oleh lagu-lagu yang diciptakan oleh H. Anang Ardiansyah.Penelitian ini berhasil ditemukan merumuskan empat fungsi yang, yaitu fungsi mendidik atau nasihat, menghibur, mengkritik, dan mengungkapkan perasaan.Semua fungsi ini ditemukan berdasarkan kutipan sejumlah lirik dalam beberapa lagu.Kutipan-kutipan ini merupakan representasi dari fungsi yang dimiliki oleh lagu yang diciptakan oleh $\mathrm{H}$. Anang Ardiansyah.Pembahasannya adalah sebagai berikut.

\section{Fungsi Mendidik atau Nasihat}

Lagu yang diciptakan oleh $\mathrm{H}$. Anang Ardiansyah dapat menjadi nasihat atau sarana pendidikan bagi para penikmatnya.Nasihat yang disampaikan merupakan pandangan masyarakat dalam melihat bagaimana seseorang seharusnya bertindak dan bertingkah laku.Teksnya berisi tentang nasihat yang mengarahkan pendengarnya untuk melakukan sesuatu yang baik dan sesuai dengan budaya masyarakat Banjar.Beberapa lagu H. Anang Ardiansyah yang berfungsi memberikan nasihat adalah sebagai berikut. 
Volume 7 Nomor 1, April 2021

Burung galatik tarbang sakawan

Hinggap batinggir hinggap batinggir dibatang buluh

Hinggap batinggir hinggap batinggir dibatang buluh

Apiklah apik bakawan-kawan

janganlah sampai janganlah sampai basumpah bisu

janganlah sampai janganlah sampai basumpah bisu

Artinya

(Burung gelatik terbang sekelompok)

(Hinggap bertengger, hinggap bertengger di batang buluh)

(Hinggap bertengger, hinggap bertengger di batang buluh)

(berhati-hatilah berteman)

(Jangan sampai, jangan sampai bersumpah bisu)

(Jangan sampai, jangan sampai bersumpah bisu)

(H. Anang Ardiansyah, Papadah)

H. Anang Ardiansyah membuat sebuah lagu yang berjudul Papadah yang berarti nasihat.Sesuai dengan judulnya, secara khusus lagu ini berisi sejumlah nasihat agar pendengarnya melakukan tindakan yang baik.Nasihatnya antara lain, menjaga tali silaturahmi dengan baik, jangan bersumpah palsu, dan mematuhi nasihat yang diberikan oleh orang yang lebih tua.

Dalam kutipan ini, H. Anang Ardiansyah menasehati pendengarnya agar mereka tidak melakukan sumpah bisu. Istilah ini bermakna sumpah palsu atau sumpah yang diucapkan hanya untuk meyakinkan orang yang tidak disertai niat untuk melaksanakan apa yang diucapkannya.Tindakan ini merupakan tindakan yang tidak baik. Melalui lagunya, H.Anang Ardiansyah menasehati para penikmat lagunya untuk tidak melakukan hal tersebut.

Selain itu, H. Anang Ardiansyah juga menasehati untuk selalu menjaga silaturahmi dengan teman-teman atau orang-orang yang ada di sekitar mereka.Kutipan yang dimaksud ialah "Apiklah apik bakawan-kawan".Kata apik dalam bahasa Banjar berarti apik, hemat, berhati-hati (Hapip, 2008: 7).Maksud dari kutipan ini memberitahu pendengarnya agar selalu berhati-hati dalam berteman.Bentuk kehati-hatian ini sangat luas meliputi perkataan atau perbuatan.Sedapat mungkin tali silaturahmi terus terjaga tanpa ada konflik. Kehati-hatian dalam perkataan antara lain dengan tidak mengatakan sesuatu yang dapat menyakiti perasaan mitra tuturnya. Kehatihatian dalam perbuatan antara lain dengan menolong ketika sedang kesulitan, menjenguk orang yang sakit, membantu dalam kegiatan sosial, dan sebagainya.

Selain menjaga silaturahmi dan kejujuran, H. Anang Ardiansyah dalam lagu Papadah juga menasihati agar para penikmat lagunya untuk selalu mematuhi apa saja yang telah disampaikan pada larik-larik sebelumnya dan jangan melanggar nasihat-nasihat tersebut. Kutipan yang dimaksud adalah sebagai berikut.

Baik diambil baik diambil siparadahnya

Baik diambil baik diambil siparadahnya

Ingatlah ingat lawan nang tuha

Jangan malanggar jangan malanggar sipapadahnya

Jangan malanggar jangan malanggar sipapadahnya

Artinya

(lebih baik diambil, lebih baik diambil nasihatnya)

(lebih baik diambil, lebih baik diambil nasihatnya) 
Volume 7 Nomor 1, April 2021

(Ingatlah, ingat dengan yang tua)

(Jangan melanggar, jangan melanggar nasihatnya)

(Jangan melanggar, jangan melanggar nasihatnya)

(H. Anang Ardiansyah, Papadah)

Lirik yang berisi tentang perintah untuk mematuhi nasihat H. Anang Ardiansyah ialah lirik yang berbunyi "Baik diambil baik diambil si paradahnya" yang berarti lebih baik diambil nasihatnya, sedangkan larangan melanggar nasihat ialah lirik yang berbunyi "Jangan malanggar, jangan malanggar si papadahnya" yang berarti jangan melanggar, jangan melanggar nasihatnya. Alasan yang disampaikan H. Anang Ardiansyah mengapa para penikmat karyanya harus melakukan anjuran tersebut ialah karena nasihat-nasihat itu dibuat oleh orang-orang yang memiliki pengalaman hidup yang panjang yang ditandai oleh umur yang sudah tua.Argumen ini terlihat pada lirik yang berbunyi "Ingatlah ingat lawan nang tuha" yang berarti ingatlah dengan orang yang sudah tua.

Nasihat-nasihat ini biasanya telah disampaikan secara turun-temurun selama beberapa generasi sehingga menjadi sebuah kearifan lokal yang menjadi sebuah ciri khas masyarakat yang mewarisinya. H. Anang Ardiansyah meneruskan kearifan lokal masyarakat banjar melalui lagulagu ciptaannya. Lagu lain yang mencerminkan fungsi nasihat dapat diamati pada lagu yang berjudul maiwak. Kutipan lagunya adalah sebagai berikut.

Tarik tarik jukung sampai ka pinggir

Gulung layar dibawa bulik

Angkat jukung rakat mupakat

Bawa ka pinggir rakat mupakat

Harap jukung dipalihara

Ma iwak...ma iwak...ma iwak

Tangkisung ka tanjung sila, ayu

Jukung hibak lalu sarat hibak

Kulihan gasan manfaat jadi

Rajaki sakaluarga kami

Artinya

(Tarik tarik perahu sampai ke pinggir)

(gulung layar dibawa pulang)

(angkat perahu sepakat bersama)

(bawa ke samping sepakat bersama)

(tolong perahu dipelihara)

(mencari ikan, mencari ikan)

(Tangkisung ke Tanjung Sila, ayo)

(perahu penuh kemudian sangat penuh)

(perolehan sebagai manfaatuntuk)

(Rejeki keluarga kami)

(H. Anang Ardiansyah, Maiwak)

Lagu ini menceritakan kehidupan seorang nelayan yang mencari ikan di laut.Di dalamnya tercermin sikap masyarakat membawa perahu bersama-sama ke pinggir laut.Kebersamaan ini merupakan sikap gotong royong yang menjadi cerminan budaya Banjar.Di dalamnya juga diceritakan bahwa banyak sekali manfaat yang diperoleh dari perahu, yaitu sebagai alat untuk 
mencari rejeki untuk menghidupi keluarga.Oleh sebab itu, H.Anang Ardiansyah menasihati agar para nelayan untuk memelihara perahu yang mereka miliki.

Nasihat untuk memelihara perahu merupakan kearifan lokal masyarakat Banjar yang coba ditanamkan olehH. Anang Ardiansyah.Nasihat ini terlihat pada kutipan yang berbunyi "Harap jukung dipalihara" yang berarti tolong perahu dipelihara. H. Anang Ardiansyah mengemukakan sejumlah alasan mengapa hal ini perlu dilakukan.Alasan yang pertama ialah perahu merupakan salah satu sarana untuk mempererat kekompakan masyarakat yang dicerminkan dalam sikap gotong royong.Sikap ini dapat diamati pada kutipan yang berbunyi "Bawa ka pinggir rakat mupakat".Kutipan ini bermakna perahu yang telah digunakan untuk mencari ikan dibawa ke pinggir pantai secara bersama-sama.Istilah rakat mupakat bila diartikan secara leksikal bermakna kesepakatan yang erat.Hal ini menunjukkan bahwa perahu itu tidak dibawa sendirian, tetapi dibawa secara bersama-sama.Suasana kebersamaan yang tercermin dari kegiatan gotong royong membawa perahu ke pinggir laut.

Nasihat juga dapat ditemukan dalam lagu yang berjudul Bismillah Kata Bamula.Lagu ini memiliki kandungan nilai religuis yang sangat kental.Nilai ini diikuti dengan sejumlah nasihat bagi para penikmat lagu $\mathrm{H}$. Anang Ardiansyah.Kutipan yang mencerminkan nasihat yang dimaksud adalah sebagai berikut.

Bulan ramadhan kita puasa

Manahan nafsu lapar dahaga

Ingat nang miskin bazakat fitrah

Fakir sangsara aduh kasihan Nauzubillah

Aaa...

Lamun balabih harta dibari

Sudah panggilan kita bahaji

Makah Madinah jarahi nabi

Mambari salam ya rasulallah salamuna'laih

Artinya

(Bulan Ramadan kita puasa)

(menahan nafsu lapar dahaga)

(Ingat yang miskin berzakat fitrah)

(Fakir sengsara aduh kasihan naudzubillah)

(aaa...)

(Bila berlebihan harta diberi)

(sudah panggilan kita berhaji)

(Mekkah Madinah menziarahi makam nabi)

(Memberi salamya rasulallah salamuna'laih)

\section{(H. Anang Ardiansyah, Bismillah Kata Bamula)}

Lagu ini berisi tentang pengamalan agama Islam. Bagaiamana seseorang seharusnya bertindak untuk bisa disebut sebagai seorang muslim. H. Anang Ardiansyah menampilkan tentang lima rukun Islam. Pertama, mengucapkan dua kalimat syahadat dengan mengakui bahwa Allah Swt. Merupakan Tuhan yang Maha Esa dan tidak ada Tuhan lain selain-Nya, serta mengakui bahwa Nabi Muhammad Saw. Merupakan utusan-Nya untuk menyampaikan pesanpesan yang tersimpan dalam kitab suci, yaitu Al Quran. Pengakuan ini merupakan pondasi pertama dan yang paling dasar dalam rukun Islam.Kedua, perintah untuk mengerjakan salat. 
Salat merupakan rukun Islam kedua berupa ibadah kepada Allh Swt, yang wajib dilakukan oleh setiap muslim sebanyak lima kali dalam satu hari dengan syarat, rukun, dan bacaan tertentu, dimulai dengan takbir dan diakhiri dengan salam. Ketiga, zakat yang merupakan rukun Islam yang mengatur harta yang wajib dikeluarkan kepada orang yang berhak.Keempat, puasa yang merupakan rukun Islam berupa ibadah menahan diri atau berpantang makan, minum, dan segala yang membatalkannya mulai terbit fajar sampai terbenam matahari. Kelima, haji merupakan rukun Islam kelima yang harus dilakukan oleh orang Islam yang mampu dengan mengunjungi kota Mekkah di Saudi Arabia pada bulan haji (Zulhijah) dengan mengerjakan amalan, seperti ihram, tawaf, sai, dan wukuf. Kelimanya ditampilkan H. Anang Ardiansyahdalam lirik lagu ini.

Nasihat yang paling jelas mendorong para penikmat lagu ialah untuk melakukan tindakan pada rukun Islam yang ketiga, yaitu zakat.Hal ini terlihat pada lirik yang berbunyi Ingat nang miskin bazakat fitrah, fakir sangsara aduh kasihan nauzubillah, dan Lamun balabih harta dibari.Pertama-tama H. Anang menyuruh agar para penikmat lagunya untuk mengingat orangorang yang miskin. Dengan demikian, mereka akan tahu bagaimana sulitnya hidup dalam ekonomi yang pas-pasan. Hal ini akan menumbuhkan rasa empati bagi pendengar sehingga mereka akan terdorong untuk menolong mereka. Pertolongan yang diharapkan oleh $\mathrm{H}$. Anang Ardiansyah ialah melalui zakat yang merupakan salah satu rukun dalam Islam. Fungsi nasihat yang lain terlihat pada lagu yang berjudul Panjang Balikat.

Papadah nang tuha tuha

Pamali manguliat rahat makan

Tabiat panjang balikat

Maungut sambil basangga wihang

balingkur bahaharian teh kopi kada kasurungan

Artinya

(Nasihat yang tua, tua)

(Pamali manguliat ketika makan)

(Naluri panjang balikat)

(Merenung sambil bersandar di tiang)

(Berselimut seharian, teh kopi tidak habis diserahkan)

(H. Anang Ardiansyah, Panjang Balikat)

Lagu ini menceritkan tentang nasihat para orang tua yang melarang orang-orang agar tidak bermalas-malasan.Nasihat ini melarang mereka agar tidak merenggangkan badan ketika sedang makan, mengkhayal sambil bersandar di tiang, dan berselimut di kamar sambil minum seharian penuh.Kegiatan-kegiatan ini menurut filosofi orang tua Banjar merupakan kegiatan yang tidak produktif.Orang-orang seperti ini dinilai sebagai orang malas yang sangat buruk di mata masyarakat. H. Anang Ardiansyah tidak secara langsung menasihati pendengarnya, dia hanya menyindir dengan menyebutkan tindakan-tindakan yang salah.

Sindiran tentang merenggangkan badan ketika sedang makan terlihat pada teks "Pamali manguliat rahat makan" yang berarti tidak boleh merenggangkan ketika sedang makan.Ketika sedang makan seseorang diharuskan hanya berfokus pada kegiatan itu.Masyarakat Banjar memiliki sejumlah aturan dalam makan, seperti tidak boleh menumpangkan piring yang digunakan untuk makan dengan piring kosong, menutupi makanan dengan bayangan sendiri, tidak menyisakan makanan, dan sebagainya.

Larangan mengkhayal sambil bersandar di tiang terlihat pada kutipan yang berbunyi "Maungut sambil basangga wihang".Tindakan maungut atau mengkhayal merupakan tindakan yang menunjukkan sikap malas.Mengkhayal tanpa melakukan sesuatu tidak menghasilkan apa- 
apa selain membuang waktu.Tindakan buruk yang lain ialah berselimut di kamar sambil minum seharian penuh terlihat pada kutipan "Balingkur bahaharian teh kopi kada kasurungan". Balingkur atau berselimut secara harfiah merujuk pada kegiatan yang dilakukan pada pagi hari hingga matahari tinggi.Bangun kesiangan merupakan kebiasaan yang tidak baik.Masyarakat Banjar merupakan masyarakat yang religius dan sangat menjunjung tinggi nilai-nilai Islam.Ketika seseorang bangun kesiangan, dia telah melanggar kewajiban salat subuh.Selain itu, banyak pekerjaan yang biasanya dimulai pagi-pagi, seperti berdagang, bertani, berternak, dan sebagainya.Oleh sebab ini, bangun kesiangan sangat buruk di mata masyarakat Banjar.

\section{Fungsi Menghibur}

Fungsi utama lagu ialah menghibur para pendengar melalui alunan lagu dan musik yang dirancang oleh penulis lagu dan penyanyinya. H. Anang Ardiansyah mampu merancang lagulagu yang enak didengar.Hal inilah yang menjadi daya tarik utama lagu ciptaannya sehingga bisa dikenal masyarakat Banjar secara luas dan mampu bertahan selama bertahun-tahun. Ada beberapa kutipan lagu yang menunjukkan lirik-lirik yang tujuan utamanya untuk menghibur pendengar.Kutipan yang dimaksud adalah sebagai berikut.

Saji panas-panas tarung babanam kawalnya

sacubikan sambal habang hirisakan ramania

masakan iwak garih, garih talang di santani

atawa basayur manis bilungka katu diwaluhi

Artinya

(Sajikan ketika panas temannya terong bakar)

(Satu sendok sambel merah potongkan buah ramania)

(Masak ikan kukus, ikan telang dengan santan)

(Atau dengan sayur manis timun katu dengan labu)

(H. Anang Ardiansyah, Sambal Raman)

Lagu ini menceritakan tantang makanan-makanan tradisional Banjar yang sangat populer.Makanan ini sangat sederhana karena tidak memerlukan bahan yang sulit atau mahal.Oleh sebab itu, makanan ini dapat dibuat oleh siapa saja.Meskipun sederhana, makanan ini cukup lezat sehingga banyak masyarakat Banjar yang membuatnya untuk dimakan seharihari.Hal inilah yang mendorong H. Anang Ardiansyah untuk membuat lagunya.

Lagu ini secara garis besar hanya memberikan hiburan tanpa tujuan khusus. H. Anang Ardiansyah membuat pendengarnya membayangkan bagaimana makanan tersebut. Bayangan ini akan membuat pendengarnya merasa lapar atau sekedar ingin menikmatinya saja.Salah satu lirik yang mendeskripsikan makanan yang menggoda pendengarnya, yaitu "Sacubikan sambal habang hirisakan ramania" yang berarti satu sendok sambal merah potongkan buah ramania.Sambal biasanya selalu menjadi hidangan yang menemani makanan apapun.Bahkan, ada sebagian orang yang merasa kurang bila tidak disertai sambal.Dorongan inilah yang membuat lagu ini menjadi hiburan tersendiri bagi pendengarnya selain musik dan penanyi yang menyanyikannya. Lagu lain yang mengandung hiburan kepada para pendengarnya dapat diamati pada lagu yang berjudu Curiak. Kutipannya adalah sebagai berikut.

Wayahini salawar kada batali

Sakit tumbal sudah kadada lagi

Pantun ini wawara urang bahari

Pantun ini wawara urung banjar 
Volume 7 Nomor 1, April 2021

Curiak siburung palung

Bakumpul lalu tarabang

Bakuriak maminta tulung

Bisulnya pacah tagapit lawang

Artinya

(Saat ini celana tidak bertali)

(sakitumbal sudah tidak ada lagi)

(Pantun ini kesengajaan orang zaman dulu)

(Pantun ini kesengajaan orang zaman dulu)

(Curiak si burung palung)

(Berkumpul kemudian terbang)

(Berteriak meminta tolong)

(Bisulnya pecah terjepit pintu)

(H. Anang Ardiansyah, Curiak)

Lagu ini menceritakan tentang sebuah pantun yang dibuat oleh orang Banjar zaman dahulu.Pada bagian awal, pantun menceritakan tentang salah satu jenis burung yang disebut curiak oleh masyarakat Banjar.Seteah itu, bagian isi pantun ini mengemukakan tentang sebuah teriakan yang ternyata disebabkan oleh bisul orang itu sedang terjepit pintu.

Lirik lagu ini tidak mengandung tujuan apapun selain menghibur para pendengarnya.Penulis berusaha memunculkan humor dari penderitaan yang dialami oleh orang yang dimaksud. Sebenarnya, terkesan sarkastis mengemukakan kondisi dalam pantun ini.Meskipun demikian, kondisi ini juga dapat memunculkan tawa karena ada unsur di dalamnya. Hal ini didukung oleh cara penulis menyampaikannya dalam bentuk lagu. Irama yang buat dengan tempo yang cepat. H. Anang Ardiansyah menonjolkan irama lagu untuk menghibur para pendengarnya.Lirik itu ikut menunjang tujuan penulis karena para pendengarnya tidak hanya dihibur melalui irama yang enak didengar, tetapi juga humor yang membuat orang tertawa ketika mendengarnya.

\section{Fungsi Mengkritik}

H. Anang Ardiansyah juga bisa menggunakan lagunya sebagai sarana kritik sosial. Dia mengkritik perilaku-perilaku masyarakat yang tidak sesuai dengan norma dan budaya masyarakat Banjar. Perilaku buruk yang dimaksud ialah malas dan kontrol diri yang kurang.Kritik tentang kontrol diri yang kurang dapat diamati pada lagu berjudul Oto Biru.Hal ini terlihat pada kutipan berikut ini.

rajin minta batambah

babibisikan sambil mambuka panci

galang amas satabah

ujarpang habar basusuk matahagi

panglaris diri

Si si baju biru

kambang bungas nang malayani

nang sudah balu barapakali

Batu Botok warung Mahaji

Sopir oto barusak hatii

Artinya

(Rajin minta tambah) 
Volume 7 Nomor 1, April 2021

(berbisik ketika membuka panci)

(gelang emas sepaket)

(Katanya menggunakan susuk matahagi)

(penglaris diri)

(Si baju biru)

(kembang cantik yang melayani)

(yang sudah janda beberapa kali)

(Batu Botok warung Bu Haji)

(Supir oto merusak diri)

(H. Anang Ardiansyah, Oto Biru)

Lagu ini menceritakan seorang supir yang tertarik dengan seorang janda yang bekerja di sebuah warung makan.Penulis mengatakan bahwa perempuan ini menurut desas desus yang beredar menggunakan sejenis susuk yang bertujuan untuk menarik perhatian lawan jenis.Supir yang tidak bisa menahan diri, semakin menjadi-jadi ketika berhadapan dengan kondisi ini.

H. Anang Ardiansyah mengkritik dua pihak yang terdapat dalam lirik lagunya, yaitu perempuan dan supir.Perempuan yang digambarkan dalam lirik lagunya menggunakan seluruh daya tarik yang ada dalam dirinya untuk memikat para pembeli di warung tempat dia bekerja. Sebagai seorang perempuan, menurut norma masyarakat Banjar hal ini merupakan tindakan yang salah. Citra buruk perempuan ini ditambah lagi dengan statusnya yang telah menjadi janda beberapa kali.Hal ini menggambarkan buruknya perilaku perempuan ini karena tidak bisa menahan diri terhadap lawan jenis. Kritik yang ditujukan kepada supir ialah karena ketidakmampuan dia dalam mengendalikan diri. Tindakan-tindakan tersebut menurut H. Anang Ardiansyah tidak bagus, terlihat pada kutipan yang berbunyi "Sopir oto barusak hatii" yang berarti supir oto merusak hati. Hal ini jelas mengatakan bahwa tindakannya hanya akan merusak diri sendiri dan mendatangkan keburukan saja bagi pelakunya. Kritik yang lain ditujukan kepada orang yang malas. Hal ini terlihat pada lagu berjudul Panjang Balikat.Kritik yang dimaksud dapat diamati pada kutipan berikut ini.

Mie mie kambing

Makan kulit tiwadak

Babaju handak bingking bagawi kada handak

Ngarani si Panjang Balikat ngarani panjang balikat

Artinya

(Mie, mie kambing)

(Makan kulit cempedak)

(berpakaian ingin bagus, bekerja tidak mau)

(Inilah si Panjang Balikat namakan Panjang Balikat)

(H. Anang Ardiansyah, Panjang Balikat)

Lagu ini menceritakan tentang perilaku seorang pemalas, yaitu orang yang ingin memiliki pakaian yang bagus, tetapi tidak mau bekerja. H. Anang Ardiansyah mengajak pendengarnya untuk menamai orang seperti ini dengan sebutan Si Panjang Balikat.Kata balikat berpadanan dengan kata belikat dalam bahasa Indonesia, yaitu tulang yang menghubungkan tulang punggung dengan pangkal lengan.Kata ini bermakna lamban bergerak atau malas.

H. Anang Ardiansyah mengkritik orang seperti ini dengan ejekan Panjang Balikat.Secara tidak langsung, dia juga mengajak para pendengarnya untuk ikut mengutuk perilaku seperti itu dengan memberi label ini.Kritik ini disampaikan karena sikap malas merupakan sikap yang dikutuk oleh masyarakat Banjar. Orang seperti ini cenderung tidak 
produktif dalam ekonomi dan hanya mengharapkan orang lain. Akibatnya, orang-orang yang ada di sekitarnya hanya akan merasakan susah ketika berada di dekatnya.

\section{Fungsi Mengungkapkan Perasaan}

Seni merupakan salah satu sarana untuk mengungkapkan perasaan bagi penciptanya.Melalui karyanya, seorang seniman dapat mengungkapkan berbagai kegundahan yang ada dalam dirinya baik mengenai persoalan yang terjadi di masyarakat atau dalam diri pribadi seniman itu sendiri.Sebagian lagu-lagu yang diciptakan H. Anang Ardiansyah juga mengekspresikan perasaannya ketika menghadapi suatu persoalan.Lagu yang dimaksud adalah sebagai berikut.

Latifah katuju aku lawan di ikam

Nang pintar mangaji nang pintar jua baharaguan

Latifah katuju banar aku wan ikam

Imbah katam aku badatang

Bulan mulut kita kawinan

Artinya

(Latifah aku sangat senang dengan kamu)

(Yang pintar mengaji, yang pintar juga memelihara rumah tangga)

(Latifah aku sangat senang dengan kamu)

(Setelah panen aku melamar)

(bulan Rabiul Awal kita menikah)

(H. Anang Ardiansyah, Latifah)

Lagu ini menceritakan tokoh dalam lagu yang sangat menyukai seorang perempuan yang bernama Latifah. Tokoh ini menyukainya karena perilakunya yang baik, seperti pandai membaca ayat-ayat suci Al Quran, tetapi tetap diiringi dengan kepandaian dalam mengurus berbagai persoalan rumah tangga.Hal ini mendorong tokoh untuk segera menikahi Latifah. Dalam lagu diceritakan bahwa sang tokoh akan langsung melamar Latifah setelah mempunyai uang yang cukup, yaitu setelah panen. Setelah itu, pada bulan Rabiul Awal atau Bulan Maulid dia segera malangsungkan pernikahan. Bulan maulid merupakan bulan ketika Nabi Muhammad saw. lahir. Pada bulan ini, masyarakat Banjar biasanya sangat ramai di berbagai tempat melaksanakan perayaan maulid atau perayaan hari kelahiran Nabi Muhammad saw.

Meskipun tokoh yang dimaksud dalam lagu itu bukan H. Anang Ardiansyah sendiri, secara tersirat dia mengungkapkan perasaannya atau pandangannya tentang perempuan yang baik.Dia melihat bahwa, seorang perempuan dapat dikatakan baik dan dapat menjadi idaman para lelaki, bila dia memiliki dua hal utama, yaitu ketaatan dalam beribadan dan beragama, serta keterampilannya dalam mengurus rumah tangga.

Lagu lain yang mencerminkan perasaan H. Anang Ardiansyah dapat diamati pada lagu berjudul Dihunjuran Mahakam. Lagu ini secara khusus menggambarkan berbgai kenangan masa lalu H. Anang Ardiansyah.Lagu yang dimaksud dapat diamati pada kutipan berikut ini.

Aku taisak manangis dijaman Japang abahku hilang

Waktu bapisahhan sampat balambaian

Dimana sidin dimana kuburan diMahakam

Artinya

(Aku menangis tersedu di zaman Jepang ayahku hilang)

(Ketika berpisah sempat saling melambai)

(Di mana beliau, di mana kuburan di Mahakam) 
(H. Anang Ardiansyah, Dihunjuran Mahakam) Lagu ini menceritakan kesedihan yang dialami H. Anang Ardiansyah ketika mengingat ayahnya. Dia terpisah dengan ayahnya ketika masih kecil di zaman penjajahan Jepang.Hingga saat ini, H. Anang Ardiansyah tidak mengetahui di mana keberadaan ayahnya.Kuburannya sekalipun tidak diketahui di mana.Perpisahan ini sangat menyakitkan bila diingat.

\section{SIMPULAN}

Dalam struktur lagunya, H. Anang Ardiansyah membuat pengulangan suatu bagian dan pengulangan dengan perubahan dalam lirik-lirik yang diciptakannya. Pengulangan suatu bagian ialah pengulangan bait secara penuh tanpa mengalami perubahan. Efek yang muncul ada tiga, yaitu menjaga alur cerita dalam lagu, menonjolkan pesan yang disampaikan, dan menjaga dinamika lagu. Pengulangan dengan perubahan yang dimaksud ialah pengulangan bait pada beberapa baris pertama memang sama, tetapi pada beberapa baris sesudahnya mengalami perubahan. Efek yang muncul dari bentuk ini ialah menjaga jalinan hubungan antar lirik pada lagu dan membuat lagu lebih indah didengar.

Dalam penelitian ini berhasil merumuskan empat fungsi, yaitu fungsi mendidik atau nasihat, menghibur, mengkritik, dan mengungkapkan perasaan. Fungsi mendidik menggambarkan pandangan masyarakat dalam melihat bagaimana seseorang seharusnya bertindak dan bertingkah laku. Teksnya berisi tentang nasihat yang mengarahkan pendengarnya untuk melakukan sesuatu yang baik dan sesuai dengan budaya masyarakat Banjar. Fungsi menghibur dalam lagu ialah untuk membuat lagu-lagu yang didengarkan agar enak didengar. Hal inilah yang menjadi daya tarik utama lagu ciptaannya sehingga bisa dikenal masyarakat Banjar secara luas dan mampu bertahan selama bertahun-tahun.

\section{DAFTAR PUSTAKA}

Effendi, Rustam. 2010. "Cucupatian (Teka-teki) Banjar: Analisis Struktur, Fungsi, Dan Nilai Budaya." Masyarakat Indonesia, Vol. 36, No. 2, 2010, pp. 209-243.

Hapip, Abdul Djebar. 2008. Kamus Banjar Indonesia. Banjarbaru: Rahmat Hafiz Al Mubaraq.

Mannion, C. M., \& Sanatullova-Allison, E. 2012. Applying the theory of linguistic relativity to music-an initial exploration. International Journal of Arts \& Sciences, 5(3), 455-475. (http://search.proquest.com/ docview/1284080689?accountid=62696).

Rafiek, M. 2012. Menyelami Rahasia Kata-Kata: Kajian dan Apresiasi Puisi Indonesia. Yogyakarta: Pustaka Pelajar.

Saro, Ahmad dan Amin Kadir.1993. Struktur Sastra Lisan Mori.Jakarta: Depdikbud.

Teeuw, A. 1983.Sastra dan Ilmu Sastra.Jakarta: Pustaka Jaya.

Tutoli, Nani. 1990. Tanggomo Salah Satu Ragam Lisan Gorontalo.Jakarta: Intermasa.

Wellek, Rene dan Austin Waren. 1989. Teori Kesusastraan. Terjemahan Melanie Budianta. Jakarta: Gramedia.

Zaidan, Rustapa, Hani’ah. 2007. Kamus Istilah Sastra. Jakarta: Balai Pustaka. 